\title{
Things I've Learned About Personality From Studying Political Leaders at a Distance ${ }^{1}$
}

\author{
David G. Winter \\ University of Michigan
}

\begin{abstract}
Studying the personalities of political leaders requires methods of measuring personality at a distance. One such method is content analysis of speeches, interviews, and other texts. This article reviews the author's research on achievement, affiliation, and power motives of U.S. presidents and other leaders and draws the following conclusions: (1) motivation and personality can be objectively and reliably measured at a distance; (2) personality is complex, consisting of several different elements or kinds of variables (e.g., motives and cognitions as well as traits); (3) personality exists in social contexts, and past social contexts are embodied in personality; (4) political behaviors and outcomes can be predicted from personality, but only in contingent ("if/then") ways.
\end{abstract}

A version of this article was presented as the Henry A. Murray Award address at the annual meeting of the American Psychological Association, Toronto, August 9, 2003. Some of the research reported in this paper was supported with grants from the John and Mary R. Markle Foundation, and the United States Institute of Peace (Grant \# 046-92S). In the course of my research career, I have reason to be grateful to many people; here I single out Richard Donley, who first suggested scoring presidential inaugural addresses for motive imagery, and Abigail Stewart, for her unfailing support, advice, and comments. Correspondence concerning this article may be addressed to the author at: Department of Psychology, University of Michigan, 525 E. University Ave., Ann Arbor, MI 48109-1109. E-mail: dgwinter@umich.edu

1. I was especially honored to receive this award named for Henry A. Murray because, as intellectual genealogies are reckoned, he was my "grandfather" (or perhaps step-grandfather); also because this award was previously given to David McClelland, my intellectual "father" and mentor, to Abby Stewart, my partner in work and in life, and to so many other distinguished personologists. I am grateful to them, as well as my students and colleagues, for all they have contributed to my research career.

Journal of Personality 73:3, June 2005

(C) Blackwell Publishing 2005

DOI: $10.1111 / \mathrm{j} .1467-6494.2005 .00321 . x$ 
In planning my Henry A. Murray Award address at the 2003 American Psychological Association convention, I reflected on one major theme of my political psychology research: exploring the personalities (especially the motives) of major political leaders past and present. I have studied U. S. presidents and other heads of government; government leaders, nationalists, and rebel leaders in southern Africa; and even British sovereigns from James I (whom we remember for his commissioning the "King James Version" of the Bible) to Elizabeth II. For someone who was a history major in college before switching to psychology, it has been exciting to apply the concepts and tools of our discipline to a Richard Nixon, a Bill Clinton, or a George W. Bush.

In this article I want to describe four lessons I have learned from this work-lessons about personality and how it can be most fruitfully conceptualized and studied. I believe these lessons also apply to personality psychology generally - that is, to the study of ordinary people as well as political leaders. Hence my title, "Things I've Learned about Personality From Studying Political Leaders at a Distance." Appropriately enough, these lessons embody many of Murray's views of personality and how it should be studied.

\section{FIRST LESSON: PERSONALITY CAN BE OBJECTIVELY AND RELIABLY STUDIED WITHOUT DIRECT ACCESS}

A good deal of personality research is carried out by directly testing people, often college students, and often in laboratory contextsfollowing the path Murray (1938) took when he "explored" the personalities of Harvard undergraduates. It's easy: they're there, and we have the carrot of "extra credit" or the stick of a "participant pool requirement." We do this in spite of Sears's (1986) caution that, compared with the general population, college sophomores are relatively unformed, readily influenced, quite changeable, and, therefore, highly inconsistent.

Most living political leaders, however, are not available for direct testing or interviews; even if they were, publicizing their scores would probably raise ethical issues. And the really interesting leaders are mostly dead. To adapt a quotation from Glad (1973), they have taken their Oedipus complex, their authoritarianism, and their 
power motivation with them. (The upper limit of direct access was probably reached by DiRenzo, 1967, who obtained measures of dogmatism from Italian parliamentary deputies, and Altemeyer, 1996, who collected mailed questionnaires from United States state legislators - though we don't actually know who filled out these questionnaires!)

Denied direct access, those who study political leaders, past and present, have had to develop a variety of indirect means for measuring personality "at a distance" (see, for example, the recent collections of articles in Feldman \& Valenty, 2001, and Valenty \& Feldman, 2002). Some researchers look for patterns in known biographical facts (Post, 2003), perhaps using formal systems of clinical diagnostic categories (Immelman, 1993, 2002). Others ask experts to rate leaders by using standard personality rating scales (Rubenzer, Faschingbauer, \& Ones, 1996, 2000) or Q-sorts (Kowert, 1996). There is, however, one kind of data from political leaders that is produced and preserved in abundance-namely, words. Thus, many at-a-distance researchers do content analyses of leaders' verbal or written texts: speeches, interviews, and even government documents (see Winter, 1992). It is thereby possible to measure a wide variety of personality characteristics of otherwise inaccessible people: for example, integrative complexity (Suedfeld \& Rank, 1976), explanatory style (Satterfield \& Seligman, 1994), nationalism, and internal control of events (Hermann, 1980).

\section{Content Analysis of Motive Imagery}

My own work involves using content analysis to measure three kinds of motive imagery - achievement, affiliation, and power (Winter, 1987, 1991, 2002a, 2003a). This technique draws directly on Murray's conceptual and methodological innovations. First, it is a lineal descendent of the Thematic Apperception Test (TAT) developed by Murray (with the assistance of Cecilia Roberts and especially Christiana Morgan; see Anderson, 1999), and modified by David McClelland (see Winter, 1998b). Second, these three motives represent the principal dimensions of Murray's list of approximately 20 basic human motives (Winter, 1996, pp. 122-125, 138-140).

Some examples will illustrate the value of this particular at-a-distance technique, not only to confirm laboratory findings, but also to 
Table 1

Motives and Outcomes Among U.S. Presidents

\begin{tabular}{lccc}
\hline & \multicolumn{2}{c}{ Correlation with motive score: } \\
\cline { 2 - 4 } Outcome variable & Achievement & Affiliation & Power \\
\hline Rated greatness $(n=29)$ & .07 & .09 & $.40^{*}$ \\
War entry $(n=31)$ & -.03 & .16 & $.52^{* * *}$ \\
Arms limitation treaty $(n=14)^{1}$ & .13 & .40 & .05 \\
Scandal $(n=29)$ & .15 & $.40^{*}$ & .01 \\
Barber's $(1992)$ typology & & & .87 **** \\
$\quad$ Active positive $(n=11)$ & -.07 & .37 & -.32 \\
$\quad$ Active negative $(n=11)$ & $.84^{* * *}$ & .03 & .19 \\
Historians' ratings & & & .26 \\
$\quad$ Idealism $(n=29)$ & $.51^{* *}$ & .19 & .27 \\
$\quad$ Flexibility $(n=29)$ & -.22 & & \\
\hline
\end{tabular}

Source: Adapted from Winter (2002a).

$* p<.05 .{ }^{* *} p<.01 .{ }^{* * *} p<.001$.

${ }^{1}$ This variable is only defined for those presidents who served after there began to be arms limitation conferences in the late nineteenth century.

extend them. Table 1 shows motive correlates of U.S. presidents (based on Winter, 2002a). ${ }^{2}$ As shown in the first row of the table, the level of power motivation in a president's first inaugural address is significantly related to historians' ratings of his greatness. Presidential power motivation also predicts U.S. entry into war (which perhaps says something about the implicit standards historians use to evaluate presidents). In contrast, affiliation motivation is associated with concluding arms limitation agreements, but also with political scandals. (As an aside, I would add that developing objective operational definitions of such presidential outcomes as "war" and

2. One could ask whose motives are measured by this procedure (or any other content analysis) - those of the speaker or motives of the speechwriters. While speechwriters may draft the words and images, leaders select speechwriters and edit their work; good speechwriters know how to adapt to the goals and style of their clients. However, as an alternative interpretation, one could view the speeches as reflecting the motives of the loose collectivity called "the administration" and labeled with the leader's name only as an eponym (see Winter, 1995, pp. 117-118; 2002, pp. 46-47). 
"scandal" is one of the great challenges and pleasures of at-a-distance research.)

\section{Achievement Versus Power Motivation}

Notice that achievement motivation does not predict presidential greatness. Why not, since the achievement motive is so consistently associated with success as an entrepreneur (see McClelland, 1961; Winter, 1996, pp. 141-142)? Ratings of presidents by political scientists and historians suggest an answer. Power-motivated presidents are classified as "active-positive" by Barber (1992); that is, they invest a good deal of energy in their job, and they enjoy it. In contrast, presidents scoring high in achievement motivation tend to end up in Barber's "active-negative" category: they are energetic, but they do not seem to derive much pleasure from the job. Why not? Other ratings suggest that achievement-motivated presidents enter office with considerable idealism. Sooner or later, this idealism seems to collide with the inevitable opposition, compromises, cost overruns, delays, and recalcitrant bureaucracies that are inherent in politics. For achievement-motivated presidents, then, politics becomes a quagmire that traps them in rigid adherence to failing policies: for example, Woodrow Wilson, Herbert Hoover, Richard Nixon, and Bill Clinton during his first two years - all cases where achievement motivation was high (compared to other presidents) and greater than power.

Contrasting with this rigidity in politics, however, achievementmotivated people are quite flexible in business settings, using feedback to modify performance (McClelland, 1961, pp. 231-233; McClelland \& Winter, 1969, pp. 51-54). Perhaps the difference has to do with control. Achievement-motivated people function best when they have considerable personal control (McClelland, 1961, pp. 228-230; McClelland \& Winter, 1969, pp. 250-255), for example, in sales and as entrepreneurs, especially in small research-and-development ventures (Wainer \& Rubin, 1969) and in progressive, larger corporations (Winter, 1996, p. 141). A study by McClelland and Pilon (1983) suggests that people high in achievement motivation learn such control, even extending to their autonomic functions, relatively early in childhood. Thus we can speculate that adult situations involving lack or loss of control may rearouse nightmarish fears of childhood. 
In contrast to business leaders, political leaders have much less direct control (at least in democratic polities). In politics, personal control is not a given, but must be continually created, negotiated, and "schmoozed." In such contexts, achievement-motivated political leaders seem to engage in a compulsive series of unsuccessful attempts to wrest control from politicians and bureaucrats in order to reestablish their own control once and for all-for example, by trying to go over the heads of Congress (as did Wilson), by cutting legal corners (as did Nixon), or by micromanaging (as did Carter).

In limited-control situations such as politics, therefore, achievement motivation may foster a kind of meritocratic tyranny, a tyranny of the person with the "one best answer." For example, in a sample of world leaders, those who came to power through a coup d'etat were significantly higher than the others in achievement motivation, but not power (see Winter, 2002a). Thus, it is possible that, in some circumstances, achievement motivation casts a latent, authoritarian "shadow." This hypothesis, derived from at-a-distance research, could be further explored in more conventional mainstream laboratory studies. Meanwhile, these results suggest that drawing political leaders from the ranks of achievement-motivated entrepreneurs (as may happen more and more in an era of globalized capitalism) may pose risks to democratic values.

\section{Case Studies of Kennedy and Clinton}

The contrasting roles of power and achievement motivation in politics can be illustrated by quantitative case studies of single political leaders. Table 2 presents results from a study of President John F. Kennedy during his first 6 months in office (January 25-July 19, 1961; see Winter, 1991, 2002a). The table gives the relationships between Kennedy's motives, coded from his spontaneous responses to questions at each of his first 13 domestic news conferences, and how he spent his time during the 2 days before and 2 days after that news conference (coded from the official daily appointment records at the Kennedy Presidential Library). When his power-motive level was relatively high, Kennedy arrived at the Oval Office earlier and put in a longer day. These days were filled with speeches, scheduled time with friends, or unscheduled time. Taken together, these three activities seem to reflect a zest for the job and flexible use of time. (The significant correlation with midday breaks may reflect another, less 
Table 2

Kennedy Motive Imagery in News Conferences and Schedule of Presidential Time on Adjacent Days

\begin{tabular}{lccc}
\hline & \multicolumn{3}{c}{$\begin{array}{c}\text { Correlation with motive score in } \\
\text { news conference: }\end{array}$} \\
\cline { 2 - 4 } Presidential schedule \pm 2 days & Achievement & Affiliation & Power \\
\hline Early arrival in oval office & $-.48^{+}$ & .27 & $.70^{* *}$ \\
Midday break time in living quarters & $-.63^{*}$ & -.05 & $.48^{+}$ \\
Total duration of working day & -.09 & .05 & $.47^{+}$ \\
Working time spent on: & & & .03 \\
$\quad$ Scheduled working appointments & -.39 & .09 & .03 \\
Scheduled appointments-friends & -.30 & $-.55^{+}$ & $.72^{* * *}$ \\
Unscheduled time in office & -.37 & .07 & $.62^{*}$ \\
Delivering speeches or "remarks" & .24 & .05 & $.50^{+}$ \\
Ceremonial events & .29 & -.21 & .19
\end{tabular}

Source: Adapted from Winter (2002a).

${ }^{+} p<.10 . * p<.05 . * * p<.01$.

attractive aspect of Kennedy's power motivation, namely his sexual dalliances; see Dallek, 2003.)

In contrast, when Kennedy's achievement motivation was relatively high, he came into the office later. He took fewer midday breaks. He also spent slightly (though not significantly) more time giving speeches and attending ceremonial occasions - events scripted for presidential control, symbolic success, and adulation-rather than the scheduled or unscheduled office time that is the daily grind of politics. ${ }^{3}$

A second case study, of the first four years of Bill Clinton's presidency, illustrates how changing levels of achievement and power motivation affect political performance (see Winter, 1998). As shown in Figure 1, Clinton's early speeches (announcement of candidacy, first inaugural, and first State of the Union message) scored high in achievement motivation relative to power. Correspondingly, the opening months of the Clinton administration are remembered for

3. Omitting two news conferences largely devoted to specific crises - the April 1961 failed Bay of Pigs invasion and the June 1961 Berlin crisis-leaves these results substantially unchanged. 


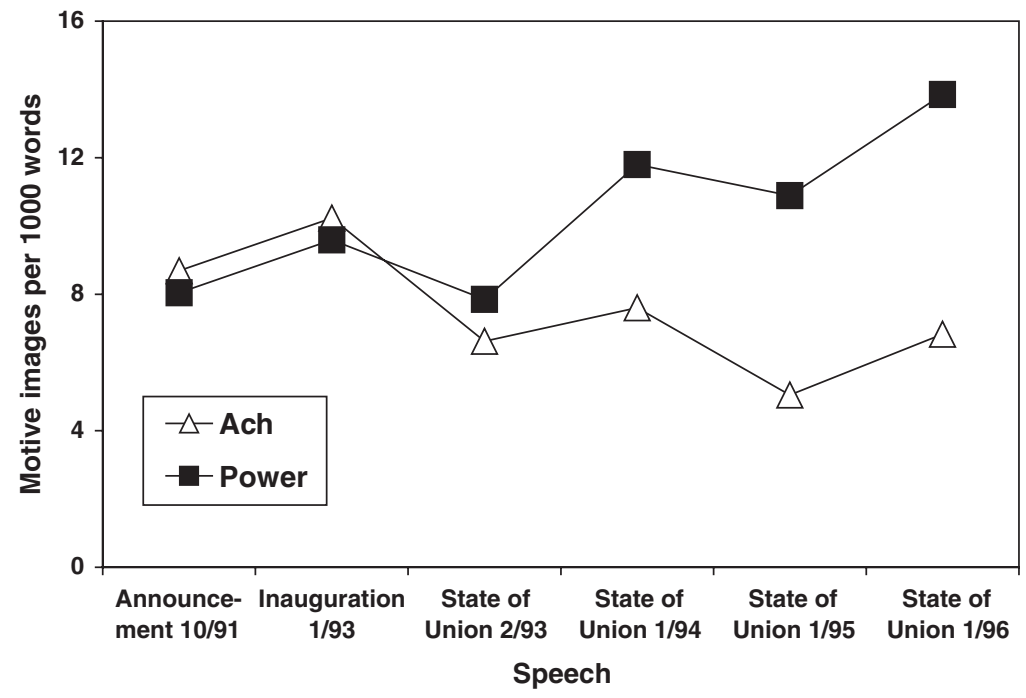

Figure 1

Clinton's achievement and power motives over time (based on Winter, 1998).

their political problems and failure. For example, the health-care reform plan was a classic achievement-motivated venture: "experts," working in secret, fashioned a "one best answer" plan without giving any attention to political realities, obstacles, or opportunities (Winter, 2001, 2002b). Then came the Republican landslide in the 1994 midterm election.

Just as Clinton was about to be written off as "irrelevant," however, his motive profile changed: power increased, and achievement went down. As would be expected from the presidential-motive correlates in Table 1 above, Clinton's political performance also improved; he fought back against the attempted "Gingrich revolution" and its shutdown of government, he won reelection in a landslide, and he even maintained high levels of public approval in the face of a Republican-led impeachment. (One could also discern other aspects of power motivation in the later Clinton: aggression, as in the 1995 threat to use force against the Bosnian Serbs and the August 1998 cruise missile attacks on suspected terrorist bases in Afghanistan and the Sudan, and exploitative risky sexuality, as in the autumn 1998 saga that dominated the national media and introduced the term "oral sex" to the front pages of The New York Times.) 


\section{Content Analysis in Mainstream Personality Research}

These examples illustrate the validity of content analysis as a way of studying personality at a distance. However, this technique can also be a valuable research tool with ordinary people, people who could be studied directly with all the usual instruments of personality measurement. Among high-ranking U.S. Navy officers (Winter, 1991), for example, power motivation scored from open-ended, critical-incident interviews (Flanagan, 1954) correlated more significantly with leadership performance than did power motivation scored from traditional TATs. Thus, content analysis of naturally occurring texts, developed as one of the only ways to study personality at a distance, may also be of use in assessing personality even when we have direct access.

Early in the 20th century, U.S. personality researchers tried to establish their "scientific" credentials by adapting item-based questionnaire techniques from the then-prestigious IQ methodology (see Winter \& Barenbaum, 1999, p. 5). In his milestone 1922 doctoral dissertation, Gordon Allport (1922) decided against analyzing people's spontaneous verbalizations in favor of quicker and easier scoring of their responses to multiple-choice questions (Nicholson, 2003, p. 92). As a result of his decision and similar decisions by other early investigators, personality research came to rely heavily upon itembased questionnaires, with their quite debatable assumptions of atomism (that complex entities can be broken down into simpler components without losing their essential characteristics), item substitutability (one item is as good as another-so long as it doesn't jeopardize coefficient alpha of the scale), and additivity (the sum of individual items is a monotonic function of the characteristic being measured). As a result, personality research has largely been constrained to that which can be assessed by added individual items. Further, it has also been plagued by two other problems: reactive effects of the testing situation itself and unwanted effects of response sets and response styles. Eighty-plus years after Allport's decision, I suggest a reexamination because systematic and objective content analysis can free us from these twin plagues.

What about reliability? Here thematic apperceptive methods have gotten an undeserved bad rap. Atkinson (1982) has argued that traditional item-based psychometric standards are not appropriate for measuring motives. That is, it is the nature of motives to be aroused 
and then satisfied - to wax and wane over time, within certain stable, disposition-like, upper and lower asymptotes that vary reliably across individuals. Along these same lines, several researchers (e.g., Lundy, 1985; Winter \& Stewart, 1977) have demonstrated that the apparent low test-retest reliability of thematic apperceptive measures is only an artifact of implicit retest instructions.

Of course, such test instructions are not a problem in at-a-distance studies, so that motive scores often show reliability figures that put them in the same league as item-based personality questionnaires. For example, in an interview-based study of southern Africa leaders (Winter, 1980), the median split-half reliability coefficient, for documents covering time periods of several months and often translated once or twice between interview and scored transcription, was +.71 . Another study, of U.S. presidential candidates, produced a coefficient of concordance of .74 for motive scores across three different occasions (Winter, 1982).

To summarize the first important lesson from the study of political leaders: they can be studied at a distance, and the technique of content analysis can even liberate us from some of the common problems of measurement in more mainstream personality research.

\section{SECOND LESSON: PERSONALITY IS COMPLEX}

As Murray (1959/1981, p. 10) put it, personality is "multiform." By that, I mean that personality consists of fundamentally different elements; not all personality variables are of the same type. Ever since Allport (1931) laid out the architecture of "personality" over 70 years ago, psychologists have been accustomed to think of personality mainly in terms of traits. Indeed, some researchers (e.g., Buss, 1989) use the word "trait" to refer to any personality variable. However, even Allport admitted the difference between "stylistic" traits and "dynamic" traits - that is, motives. Later, he added values (Nicholson, 2003, pp. 176-180). ${ }^{4}$

4. Traits can be thought of as the "adverbs" and "adjectives" of behavior, describing how we act, whereas motives are the "verbs" of behavior, describing the goals for which we strive (see Winter et al., 1998). Perhaps this is the reason why, as Saucier and Goldberg (1996, p. 31) noted, verbs cannot easily be mapped onto most trait schemes such as the Five-Factor Model. 


\section{Traits and Motives}

Conceptually, traits involve consistency of publicly observable behavior. According to current fashion, such actions are best described in terms of $5( \pm 2)$ factors. I believe that, while they are useful, such trait descriptions have their limits; they are certainly not a complete description of anyone's personality. For example, Rubenzer, Faschingbauer, and Ones (2000) surveyed over 100 historians and presidential biographers to calculate five-factor trait scores for U.S. presidents. Abraham Lincoln scored high on "openness to experience" and low on "emotional stability." Now, Lincoln's scores were based on the historians' expert judgments, which were, in turn, based on their knowledge of the facts of Lincoln's life. In other words, the trait "measures" are really just summary descriptions of Lincoln's consistent public behavior. If we then use these trait scores to explain Lincoln's behavior, aren't we only exploiting shared method variance, thereby slipping into a tautology of circular reasoning?

Furthermore, for all its "scientific" basis, does this trait description of Lincoln really tell us anything we didn't already know about himthat he was curious and read widely and that he suffered inner torments? And wouldn't such a description apply to a very large number of people in the United States (by my calculation, over 317,000 in Lincoln's time and almost 3 million in our own day $\left.{ }^{5}\right)$ ? So what have we really learned? As McAdams (1992) wrote, the five-factor trait model uses the language of first impressions and provides only the "psychology of the stranger." There must be more to personality.

In contrast to the consistency of traits, motives are variable. How a motive is expressed in behavior will depend on many factors, such as obstacles and opportunities, the time since last satisfaction, the functional substitutability of different incentives for satisfying that motive, and conflicts and fusions with other motives. For example, there are many different uncorrelated actions that could satisfy my hunger motive, depending on whether I am in my kitchen, at a restaurant, or

5. Assuming orthogonality and normal distributions, $5.48 \%$ of the population would have an openness score as high as Lincoln's (standardized) score of 1.7, and $18.41 \%$ would have a score on neuroticism as high as Lincoln's score of 0.9 , for a product of $1.008868 \%$. Multiplying this by the U.S. population of $31,443,321$ in the 1860 Census gives a product of 317,222 people; multiplying it by the United States Census Bureau's (n.d.) latest estimate of the U.S. population $(284,796,887)$ gives a product of $2,873,225$ people. 


\section{Table 3}

Combinations of Motive and Trait

\begin{tabular}{|c|c|c|}
\hline \multirow[b]{2}{*}{ Extraversion } & \multicolumn{2}{|c|}{ Affiliation, as a motive } \\
\hline & Low & High \\
\hline High & $\begin{array}{l}\text { Franklin D. Roosevelt } \\
\text { Ronald Reagan }\end{array}$ & $\begin{array}{l}\text { Harry S. Truman } \\
\text { John F. Kennedy }\end{array}$ \\
\hline Low & Calvin Coolidge & Richard Nixon \\
\hline
\end{tabular}

Source: Adapted from Winter et al. (1998).

wandering the streets of a foreign city where I do not speak the language. And glutton though I may be, I do not eat all the time; I cannot eat when there is no food (though I can fantasize food), and I will eat a lot more barbecued ribs than laboratory bran mash.

Empirically, motives and traits - even those with similar names - are unrelated. To illustrate this, consider the affiliation motive and the trait of extraversion, each involving sociable behavior. Among 36 U.S. presidents (Washington through Clinton, extraversion scores from Rubenzer et al., 1996; motive scores from Winter, 2002a), as in the general population (Winter, John, Stewart, Klohnen, \& Duncan, 1998), they are uncorrelated. A brief examination of some presidents high or low on each variable, shown in Table 3, will illustrate this independence, as well as the different ways in which they combine in behavior.

Harry Truman and Kennedy were high on both extraversion and affiliation motivation. That is, they were sociable in style and they desired companionate activity with friends. Calvin Coolidge was low on both, as befits his nickname of "Silent Cal." But now, consider Franklin Roosevelt and Ronald Reagan: superficially, they were sociable and adept at human relations, but each had an enigmatic, private core. ${ }^{6}$ Interpersonal closeness was something they could take or leave, not something they were driven to pursue.

Even more interesting is Richard Nixon's pattern: driven to seek close relations with others, but lacking the trait of extraversion that

6. Reviewing a 2002 television documentary about Reagan, movie critic Michael Christopher (2003) described Reagan as “one of the United States' most affable and gregarious leaders, Reagan also had a personal side that the public - and even those closest to him-never saw." 
would have communicated sociability and warmth. (He once described himself as an "introvert in an extravert profession"; see Mazlish, 1972/1973, p. 55.) Perhaps this curious motive-trait combination explains why many people who knew Nixon well remarked on the great contrast between his brusque awkwardness in front of large groups and his relaxed and warm manner among close friends with whom he felt comfortable (Klein, 1980, p. 133). Clearly, an introvert who is also motivated for affiliation is likely to experience a certain amount of conflict and frustration. Using the at-a-distance Nixon example to frame an hypothesis for mainstream personality research, Winter et al. (1998) found that among extraverts, affiliation motivation (as expected) is associated with successful interpersonal relationships; among introverts, however, these relationships significantly reverse (see also Winter, 1996, pp. 670-672). In other words, introverts high in affiliation motivation have affiliation-related problems. Thus, traits are not the same as motives; rather, traits channel or direct the ways in which motives are expressed in particular actions-sometimes channeling them in strange directions. ${ }^{7}$

\section{Other Elements of Personality: Comparing Kennedy and Bush}

There are still other elements of personality besides motives and traits. For example, compared to other U.S. presidents, George W. Bush's motive profile is very high in power and affiliation and about average in achievement (Winter, 2001). Among all previous presidents, Bush mostly closely resembles John F. Kennedy (using the

7. Thus, for example, several passages in Nixon's writings suggest links between love and death. In the first chapter of his autobiography (Nixon, 1978), Nixon recounted two experiences, each with a dying brother, that are the only mentions of physical and emotional intimacy in his entire account of childhood and adolescence: (1) Shortly before his younger brother Arthur's death (when Nixon was 12), "he called my mother into the room. He put his arms around her and said that he wanted to pray before he went to sleep" (p. 11). (2) Eight years later, Nixon's dying brother Harold asked his mother "to put her arms around him and hold him very close" (p. 12). Finally, in his disjointed and emotion-filled nationally televised speech to the White House staff after resigning the presidency, Nixon (1975) echoed this same theme of death and affection as he quoted Theodore Roosevelt's diary entry after the [1884] death of his young first wife Alice: "'Fair, pure and joyous as a maiden: loving, tender, and happy. ... Then by a strange terrible fate, death came to her. And when my heart's dearest died, the life went from my life forever"' (p. 632). 
method of calculating the Euclidean distance between the two motive profiles; see Winter, 1987). Also, like Kennedy, Bush is quite extraverted and not very conscientious (Immelman, 2002; Rubenzer, et al., 1996). Both presidents came from private school, Ivy League, upper-class backgrounds of wealth and privilege, with rumored-philanderer fathers ${ }^{8}$ and strong mothers.

For all these similarities, though, there is a world of difference between JFK and W. Examining these differences will suggest other elements of "multiform" personality. There is a considerable difference in intelligence - about 25 IQ points, according to the calculations of Simonton (2002; personal communication, April 3, 2003; see also Immelman, 2001). ${ }^{9}$ There are important differences in attitudes, beliefs, and values such as liberalism, right-wing authoritarianism (i.e., conventionality, obedience, and aggression; see Altemeyer, 1996), and, perhaps, acceptance versus denial of personal responsibility. ${ }^{10}$

There are also major differences of cognitive style: Kennedy scored higher in integrative complexity (Tetlock, 1981; Suedfeld, personal communication, July 28, 2003), and had a coherent verbal manner of expression, laced with irony and wit. Bush's language, in contrast, is awkward and saturated with the earnest rhetoric of conventional morality. Finally, Kennedy was willing to reconsider strongly held beliefs, which seems to reflect a greater openness to experience (see also Simonton, personal communication, April 3, 2003). Whereas, in his 1961 inaugural, Kennedy vowed to "pay any price, bear any burden ... support any friend, oppose any foe" (Kennedy, 1962, p. 1), two years later, at the height of the Cold War, he called on Americans to "reexamine our attitude toward the Soviet Union" (Kennedy, 1964, p. 461).

Table 4 brings together these comparisons, with the similarities in roman typeface and the differences italicized. We can see that Bush and Kennedy are similar in motives, some traits (extraversion), and

8. On Kennedy's father, see Goodwin (1987) and Wills (1982); on Bush's father, see Kelley (1991, p. 507) and Swan (1992).

9. Kennedy scoring at 139 , Bush at around 114.

10. Regarding responsibility, in April 1961, when the Bay of Pigs fiasco collapsed, Kennedy accepted the responsibility "because I am the responsible officer of the government" (April 21, 1961 news conference). In contrast, when Bush was shown to have used fabricated information and faulty intelligence to justify an American invasion of Iraq in his January 28, 2003, State of the Union speech, he allowed the blame to fall on various other government officials. 
Table 4

Personality Comparison of John F. Kennedy and George W. Bush

\begin{tabular}{cll}
\hline \multicolumn{1}{c}{ Kennedy } & \multicolumn{1}{c}{ Bush } \\
\hline & \multicolumn{1}{c}{ Motives $^{1}$} \\
\hline 50 & Achievement & 45 \\
74 & Affiliation & 76 \\
75 & Power & 72 \\
\hline \multicolumn{1}{c}{ Traits $^{2}$} \\
high & Extraversion \\
low & Conscientiousness & high \\
high & Openness to & low \\
& experience & \\
& Cognitions \\
\end{tabular}

Liberal

Ironic, witty verbal style

3.60

Integrative complexity ${ }^{3}$

Right-wing authoritarian Awkward verbal style

1.75

Social contexts

Irish Catholic

Wealth, Ivy League

Urban East Coast

War veteran
Anglo Methodist

Wealth, Ivy League

Samll-city Texas

Intermittent $^{4}$

(noncombatant) service

in the Texas Air

national Guard

Congress

Business

${ }^{1}$ From Winter (2002); scores are standardized on the sample of all presidential first inaugural addresses.

${ }^{2}$ Kennedy estimates based on Rubenzer, Faschingbauer, and Ones (1996; 2000); Bush estimates based on Immelman (2002) and Simonton (personal communication, April 3, 2003).

${ }^{3}$ Kennedy score from Tetlock (1981); Bush score from Suedfeld (personal communication, July 28, 2003).

${ }^{4}$ See Robinson (2000). 


\section{Table 5}

Elements of Personality

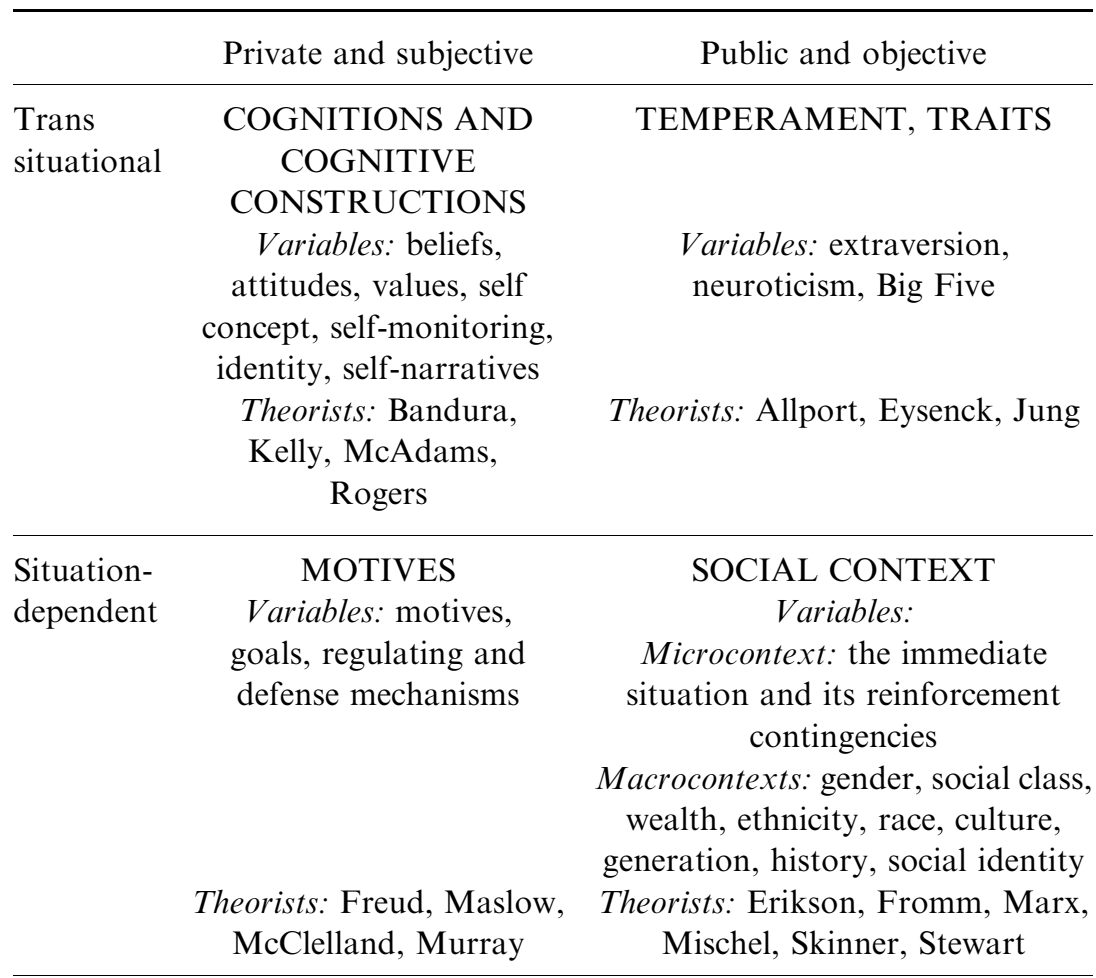

Source: Adapted from Winter (1996).

many aspects of social context. They differ on other traits (openness to experience) and other aspects of social context - for example, combat veteran versus intermittent ${ }^{11}$ National Guard "weekend warrior," urban East Coast versus small-city Texas, experience in Congress versus experience in business, and Irish Catholic versus Anglo-Episcopalian/Methodist). Most notably, they have many differences in cognitive content and style. I suggest that these four domains - traits, motives, cognitions and cognitive constructions, and social context - constitute four basic elements of personality (Winter, 1996), as shown in Table 5. Of course, in the spirit of Murray

11. See Robinson (2000). 
(and Allport), I would also add some kind of executive or "coherence" function, or "unity thema" (Murray, 1938, pp. 604-605) that binds these elements together - though the exact conceptualization, description, and measurement of such a function remains rather elusive. As shown in the table, each element has its own characteristic variables, assessment methods, and even theorists. No one element can be reduced to any other, and variables drawn from all elements are necessary for the fullest description of personality, whether at a distance or from direct contact.

\section{THIRD LESSON: PERSONALITY EXISTS IN CONTEXT AND CONTEXTS LIVE ON IN PERSONALITY}

Readers may be surprised that I include "social context" in personality as a fourth element, rather than viewing personality as something that operates in contexts. Actually, I want it both ways. Personality certainly does interact with the opportunities and obstacles of situational contexts. This can be illustrated by research on presidential greatness and success. As shown above in Table 1, historians' ratings of presidential greatness are correlated with presidents' power motivation. However, political success is a multidimensional construct, with such ratings as only one facet. In the U.S. presidential system, electoral success (margin of victory or percent of the vote) is a second facet, unrelated to historians' ratings and uncorrelated with power motivation. Rather, electoral success is predicted by the congruence of the candidate's motives with those of American society at the time, as measured through content analysis of popular literature (Winter, 1987).

Ethington (2001) demonstrated this same effect at a microlevel in a day-by-day analysis of the epic 2000 presidential campaign. She found that on a given day, whichever major candidate-Bush or Gore- had a motive profile closer to that of Jay Leno's monologue (at the beginning of the Tonight U.S. television show), that candidate showed a subsequent relative gain in the polls several days later. ${ }^{12}$ Thus, presidential personality interacts with the psychopolitical context of the electorate. (Things worked a little differently in the former Soviet Union. From Stalin to Gorbachev, the motive

12. See Parkin, Bos, and van Doorn (2003) for a discussion of the political communication importance of entertainment television programs such as the "Tonight" show. 
profile of Soviet society, as estimated through content analysis of contemporary literature, changed toward those of the Communist Party general secretaries during the years after they assumed office; see Schmitt \& Winter, 1998.)

From another perspective, though, contexts are very much a part of personality. That is, we can view personality as a series of embodied contexts - characteristics formed by environments and experiences that, once developed, are then (more or less) resistant to further alteration or are altered only with more effort than it took to form them. (I take this to be a minimal definition of "personality.") In this sense, our social contexts are part of our personalities, affecting the levels and forms of expression of all the other parts. Our gender, wealth, and position in the social class hierarchy (what Murray called "gratuities"; 1938, p. 62; see also Barenbaum \& Winter, 2003 , p. 188) and our ethnicity, race, religion, nationality and culture, generation, and collective historical memories - all these give scope, meanings, and emotional significance to "stimuli" and create affordances for behavior.

Some political examples: the Russian language uses a single word-vlast - for both "power" and "authority." How does this affect the way Russian leaders and followers understand and respond to either concept? And how are these responses further shaped by Russian historical and cultural experiences of power-for example, experiences of absolute autocracy, the "ecstasy of submission" to a charismatic leader, and leadership transition by overthrow (Ihanus, 2001, pp. 131-134), as well as - perhaps above all - an obsessive concern with secrecy (Myers, 2003)? Similarly, themes of anti-authority and autonomy are part of what it means to be "American" (see Gorer, 1948; Mead, 1943). We come from a culture where, under certain circumstances, it is acceptable to shout, "Kill the umpire!" And to make yet another contrast: for Asian leaders, "power" may mean ties of respect between patron and client, paternalism, and dependency. From an Asian perspective, the powerful leader is spared the "chore" of decision making (Pye, 1985).

The ways in which our embodied contexts shape the expression of other personality variables can be illustrated by a simple "thought experiment" (Winter \& Barenbaum, 1999, p. 19; Winter, 2003b, pp. 128-129). Consider such personality variables as power motivation, optimistic explanatory style, extraversion, and conscientiousness. Each has a clearly defined measure possessing considerable construct 
validity. Yet, imagine how differently each would have been expressed on the morning of June 6, 1944, by the following two people: (1) a white, 20-year-old American man storming "Utah Beach" during the World War II invasion of Normandy in France, and (2) a middle-aged Japanese American woman in the Utah desert, confined in the Topaz concentration camp ${ }^{13}$ set up by the U.S. government during World War II to intern citizens and residents of Japanese ancestry.

\section{LESSON FOUR: IT IS POSSIBLE (BUT RISKY) TO PREDICT POLITICAL BEHAVIOR FROM PERSONALITY}

My final lesson from studying political leaders involves predicting what they will do. Such predictions can be difficult, however, because so many features of their situations have to be taken into account. Sometimes that isn't easy; it can even be perilous.

\section{Successful Predictions}

First, a couple of successes. On the afternoon of January 20, 2001, after scoring George W. Bush's inaugural address, I began writing a brief sketch for the International Society of Political Psychology's spring 2001 newsletter (Winter, 2001). Given Bush's motive profile, I made the following predictions about his presidency:

- In foreign affairs, Bush would endorse more aggressive policies (high power motivation), for example on Iraq, depending particularly on whether the "hawk" or "dove" faction of his foreign policy advisors came to have the most influence over him. (This was back when the U.S. invasion of Iraq was just a gleam in the eyes of Donald Rumsfeld and Paul Wolfowitz.)

- In making decisions, Bush would rely on small, secluded groups of close friends and advisers who were similar to himself (high affiliation motivation), which might alienate people with different views and experience.

13. Although the term "concentration camp" might seem excessive when applied to what are now called "internment camps" or even "relocation centers," this was actually the term used by President Roosevelt at the time (see Nagata, 1993, p. xiii). 
- Bush would enjoy being president, due to his high power and below-average achievement motivation, rather than becoming frustrated in the manner of a Jimmy Carter.

- For the same motive reasons, he would demonstrate greater political effectiveness than some pundits might have expected.

- He would be vulnerable to scandals arising from the excessive influence of advisers and friends (high affiliation).

At the time of final drafting of this article (April 2004), I'll count the first four predictions as confirmed. Regarding the "aggressive foreign policy" prediction, it seems only fair to count the invasion of Iraq and not the prior war in Afghanistan as a true "confirmation," because after September 11, 2001, probably any U.S. president would have ordered some kind of military action in Afghanistan. Mounting evidence, however, suggests that the invasion of Iraq was being planned in the earliest days of the Bush administration, long before 9/11 (see Clarke, 2004; Lemann, 2001; Schorr, 2004; and Suskind, 2004).

The verdict is still out on the "scandals" prediction; however, major political scandals involving the president often only come to light during subsequent administrations. ${ }^{14}$ (Thus the famous "Teapot Dome" scandal of Harding's administration was only revealed later, during Coolidge's presidency.) In this article, I'll add another "prediction" that I could have made - call it a "retrodiction" nowbased on Bush's high affiliation motivation. Like his affiliation-motivated father, George W. Bush becomes prickly and defensive, even hostile, toward former "friends" who disagree and contradict his beliefs or desires - as, for example, with the American allies of "old" Europe when they criticized the Bush administration's invasion of Iraq.

Another possible success: Almost 25 years ago, I published a content analysis study analyzing the motives of several groups of political leaders from southern Africa, on the basis of news conferences and other interviews (Winter, 1980). The sample included White government officials of South Africa and what was then Rhodesia, Black nationalists from South Africa and soon-to-be Zimbabwe, and

14. Fragmentary details about Bush administration-corporation relationships regarding energy policy formation and Iraq supply and reconstruction contracts may be harbingers of more widespread revelations to come. 


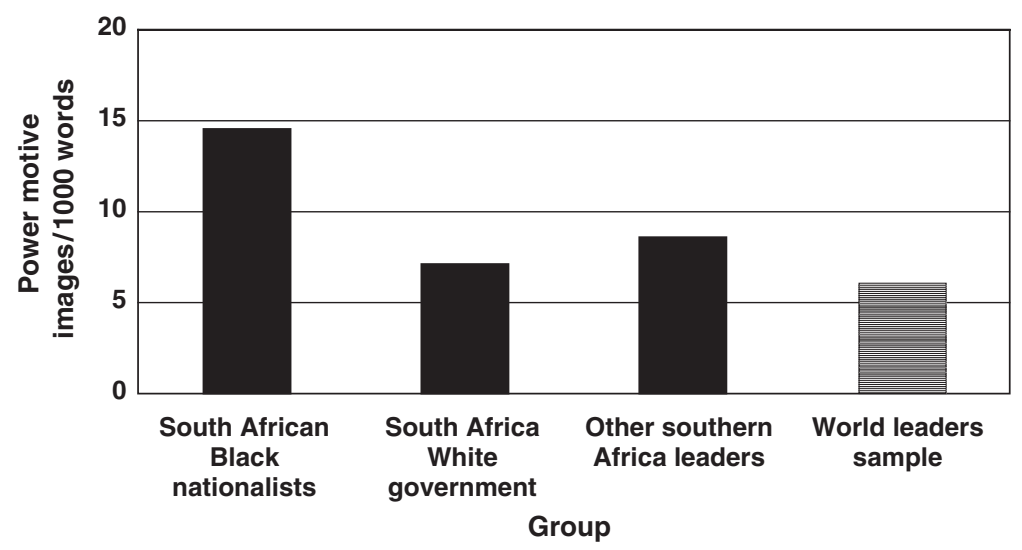

Figure 2

Power motive scores of groups of southern Africa leaders, 1974-1977.

the heads of the five so-called front-line states (Angola, Botswana, Mozambique, Tanzania, and Zambia) - all in comparison to each other and to a calibration sample of world leaders. As expected, the Black South African nationalist leaders were significantly higher than the other groups in power motivation, as shown in Figure 2. To my great surprise, however, the White leaders of South Africa-at the time, seemingly diehard defenders of the apartheid system - were not especially high in power motivation. They scored about the same as the other front-line southern Africa leaders and the world leaders sample.

From these results, the obvious prediction was that, at the end of the day, there would be no bloodbath in South Africa and that Whites would dismantle apartheid without a struggle because they lacked the elevated power motivation associated with escalation to armed conflict (see Winter, 1993). In 1980, this seemed so unlikely that I made only the cautious conjecture that apartheid might be "based on some psychological characteristic other than motivation-for example, religious beliefs and ideology, autonomy, or an intense desire to be left alone" (Winter, 1980, p. 84). Having asked whether "these scores enable us to predict the future course of political events in southern Africa," I hedged my bets with the all-purpose comment that "only history can answer this latter question" (Winter, 1980, p. 83). Therefore, I suggest motto \#1 for predicting political behavior: Be bold! Or, as the Duke of Wellington is reputed to have said, "Publish and be damned!" 


\section{Hazards of Predicting Political Outcomes}

Now about that risk of damnation. Following motto \#1, in June 1990, I sent off to the editor of Political Psychology a jointly authored manuscript analyzing the personality of President George H. W. Bush (Winter, Hermann, Weintraub, \& Walker, 1991b). On the basis of Bush-the-father's high affiliation and only average power motives (as well as his scores on several other variables), we described him as a "peacemaker, concerned with development and not prone to seek political ends through violence and war" (p. 237). Our paper was quickly accepted. This leads to motto \#2: Beware the law of hubris!

Of course, a few weeks later Iraqi President Saddam Hussein invaded and annexed Kuwait, and our affiliation-motivated President Bush, proclaiming that "this shall not stand," began the run-up to the first Gulf War. What had gone wrong with the motive-based prediction? In August I called the journal editor and asked whether we could revise our manuscript. He said no, but encouraged us to write a follow-up (Winter, Hermann, Weintraub, \& Walker, 1991a). In this article we reexamined the research literature about affiliation motivation and aggression, and noted that

Under favorable and "safe" conditions, people high in affiliation and achievement motivation are indeed cooperative bargainers. Under conditions of threat, however ... affiliation-motivated people are the least cooperative and the most suspicious and defensive bargainers. (p. 459, emphasis in original)

Now, since the elder Bush had courted Saddam Hussein with military, economic, and intelligence assistance right up to the Iraqi invasion of Kuwait, we concluded that he felt double-crossed and so turned Hussein into an enemy ("another Hitler" was his characterization). Further, Bush conducted the war in an affiliation-motivated way-originally, taking a stand in conformity with British Prime Minister Margaret Thatcher's stern lecturing and using personal telephone contact to bring together a broad coalition of world leaders. ${ }^{15}$ Thus, in some sense, Bush's actions were consistent with his motives, given the circumstances of the Iraqi invasion.

15. Perhaps another example of Bush's affiliation motivation would be his overruling military advice by ending the first Gulf War with Saddam Hussein still in 
This example helps us understand what kinds of predictions about people's behavior we can and cannot make from their personality. Could we have predicted the Gulf War in June 1990? Of course not. The Iraqi invasion of Kuwait was a surprise, certainly not predictable from any knowledge of Bush's personality. What we can do, however, is predict (and especially interpret) Bush's responses, given that unpredictable event. Thus, while our at-a-distance personality assessment portrayed Bush as disposed to peace and rational cooperation, it also implicitly suggested circumstances under which he would be likely to go to war and how he would conduct such a war.

\section{So What Can We Predict?}

We cannot always make absolute predictions from leaders' personalities because we cannot know the future situations, especially the surprising and improbable ones, that they may encounter. Murray learned this lesson during World War II when he and his OSS colleagues tried to select good spies, without knowing exactly what missions the spies would be assigned to and what unusual conditions they would encounter (Murray, 1948, pp. 450-458). Following the advice of Wright and Mischel $(1987,1988)$, we can make contingent, conditional, "if/then" predictions: that a person of type $X$ (or a person scoring high on variable $X$ ), under condition $Y$, is likely to exhibit particular behavior $Z$. We cannot know everything, but we can often know something.

My final lesson from studying leaders at a distance, then, is that in such an enterprise (as in the rest of life), a certain sense of humility is both necessary and becoming.

\section{REFERENCES}

Allport, G. W. (1922). An experimental study of the traits of personality with application to the problems of social diagnosis. Unpublished doctoral dissertation, Harvard University.

Allport, G. W. (1931). What is a trait of personality? Journal of Abnormal and Social Psychology, 25, 368-372.

Altemeyer, B. (1996). The authoritarian specter. Cambridge, MA: Harvard University Press.

power and the Iraqi Republican Guard still largely intact (thus establishing the basis for his son's "Oedipal" surpassing 12 years later). 
Anderson, J. W. (1999). Henry A. Murray and the creation of the Thematic Apperception Test. In L. Gieser \& M. I. Stein (Eds.), Evocative images: The Thematic Apperception Test and the art of projection (pp. 23-38). Washington, DC: APA Books.

Atkinson, J. W. (1982). Motivational determinants of thematic apperception. In A. J. Stewart (Ed.), Motivation and society (pp. 3-40). San Francisco: Jossey-Bass.

Barber, J. D. (1992). The presidential character: Predicting performance in the White House (4th ed.). Englewood Cliffs, NJ: Prentice-Hall.

Barenbaum, N. B., \& Winter, D. G. (2003). Personality. In D. K. Freedheim (Vol. Ed.), Handbook of psychology, Volume I: History of Psychology (pp. 177-203). Hoboken, NJ: Wiley.

Buss, A. H. (1989). Personality as traits. American Psychologist, 44, 1378-1388.

Christopher, M. (2003). Review of "Ronald Reagan: A legacy remembered." Retrieved July 16, 2003, from http://www.popmatters.com/tv/reviews/r/ ronald-reagan-a-legacy-remembered.shtml.

Clarke, R. A. (2004). Against all enemies: Inside America's war on terror. New York: Free Press.

Dallek, R. (2003). An unfinished life: John F. Kennedy, 1917-1963. Boston: Little, Brown, and Co.

DiRenzo, G. J. (1967). Personality, power and politics. Notre Dame, IN: University of Notre Dame Press.

Ethington, L. (2001, July). Campaign 2000: A time-series study of motive profiles in the U.S. presidential elections. Paper presented at the annual meeting of the International Society of Political Psychology, Cuernavaca, Mexico.

Feldman, O., \& Valenty, L. O. (Eds.). (2001). Profiling political leaders: Crosscultural studies of personality and behavior. Westport, CT: Praeger.

Flanagan, J. C. (1954). The critical incident technique. Psychological Bulletin, 51, 327-358.

Glad, B. (1973). Contributions of psychobiography. In J. N. Knutson (Ed.), Handbook of political psychology (pp. 296-321). San Francisco: Jossey-Bass.

Goodwin, D. K. (1987). The Fitzgeralds and the Kennedys. New York: Simon and Schuster.

Gorer, G. (1948). The American people: A study in national character. New York: Norton.

Hermann, M. G. (1980). Explaining foreign policy behavior using the personal characteristics of political leaders. International Studies Quarterly, 24, 7-46.

Ihanus, J. (2001). Profiling Russian leaders from a psychohistorical and a psychobiographical perspective. In O. Feldman \& L. O. Valenty (Eds.), Profiling political leaders: Cross-cultural studies of personality and political behavior (pp. 129-147). Westport, CT: Praeger.

Immelman, A. (1993). The assessment of political personality: A psychodiagnostically relevant conceptualization and methodology. Political Psychology, 14, 725-741.

Immelman, A. (2001). Bush gets bad rap on intelligence. Retrieved July 23, 2001, from http://www.sctimes.com/Election/bush011401.htm.

Immelman, A. (2002). The political personality of U.S. President George W. Bush. In L. Valenty \& O. Feldman (Eds.), Political leadership for the new 
century: Personality and behavior among American leaders (pp. 81-103). Westport, CT: Praeger.

Kelley, K. (1991). Nancy Reagan: The unauthorized biography. New York: Simon \& Schuster.

Kennedy, J. F. (1962). Inaugural address. January 20, 1961. In Public papers of the presidents of the United States: John F. Kennedy, 1961 (pp. 1-3). Washington: Government Printing Office.

Kennedy, J. F. (1964). Commencement address at American University. June 10, 1963. In Public papers of the presidents of the United States: John F. Kennedy, 1963 (pp. 459-464). Washington: Government Printing Office.

Klein, H. G. (1980). Making it perfectly clear. Garden City, NY: Doubleday.

Kowert, P. A. (1996). Where does the buck stop? Assessing the impact of presidential personality. Political Psychology, 17, 421-452.

Lemann, N. (2001, January 22). The Iraq factor. The New Yorker, pp. 34-38.

Lundy, A. (1985). The reliability of the Thematic Apperception Test. Journal of Personality Assessment, 49, 141-145.

Mazlish, B. (1973). In search of Nixon: A psychohistorical inquiry. New York: Penguin Books. (Original work published 1972)

McAdams, D. P. (1992). The five-factor model in personality: A critical appraisal. Journal of Personality, 60, 329-361.

McClelland, D. C. (1961). The achieving society. Princeton, NJ: Van Nostrand.

McClelland, D. C., \& Pilon, D. A. (1983). Sources of adult motives in patterns of parent behavior in early childhood. Journal of Personality and Social Psychology, 44, 564-574.

McClelland, D. C., \& Winter, D. G. (1969). Motivating economic achievement. New York: Free Press.

Mead, M. (1943). And keep your powder dry: An anthropologist looks at America. New York: Morrow.

Murray, H. A. (1938). Explorations in personality. New York: Oxford University Press.

Murray, H. A. (1981). Preparations for the scaffold of a comprehensive system. In E. S. Shneidman (Ed.), Endeavors in psychology: Selections from the personology of Henry A. Murray (pp. 7-51). New York: Harper \& Row. (Original work published 1959)

Murray, H. A., and staff. (1948). Assessment of men. New York: Rinehart.

Myers, S. L. (2003, August 27). Old Kremlin, new Kremlin: It's still a big secret. The New York Times, p. A4.

Nagata, D. K. (1993). Legacy of injustice: Exploring the cross-generational effects of the Japanese American internment. New York: Plenum.

Nicholson, I. A. M. (2003). Inventing personality: Gordon Allport and the science of selfhood. Washington, DC: American Psychological Association.

Nixon, R. M. (1975). Remarks on departure from the White House. August 9, 1974. In Public papers of the presidents of the United States: Richard Nixon, 1974 (pp. 630-632). Washington, DC: Government Printing Office.

Nixon, R. M. (1978). RN: The memoirs of Richard Nixon. New York: Grosset \& Dunlap. 
Parkin, M., Bos, A., \& van Doorn, B. (2003, July). The effects of informal news sources on political knowledge and attitudes. Paper presented at the annual meeting of the International Society of Political Psychology, Boston.

Post, J. M. (2003). Assessing leaders at a distance: The political personality profile. In J. M. Post (Ed.), The psychological assessment of political leaders: With profiles of Saddam Hussein and Bill Clinton (pp. 69-104). Ann Arbor: University of Michigan Press.

Pye, L. W. (1985). Asian power and politics: The cultural dimensions of authority. Cambridge, MA: Harvard University Press.

Robinson, W. V. (2000, May 24). 1-year gap in Bush's Guard duty: No record of airman at drills from 1972-73. Boston Globe, p. A8.

Rubenzer, S. J., Faschingbauer, T. R., \& Ones, D. S. (1996, August). Personality scores and portraits of U.S. presidents. Paper presented at the annual meeting of the American Psychological Association, Toronto.

Rubenzer, S. J., Faschingbauer, T. R., \& Ones, D. S. (2000). Assessing the U.S. presidents using the revised NEO Personality Inventory. Assessment, 7, 403420.

Satterfield, J. M., \& Seligman, M. E. P. (1994). Military aggression and risk predicted by explanatory style. Psychological Science, 5 (2), 77-82.

Saucier, G., \& Goldberg, L. R. (1996). The language of personality: Lexical perspectives on the five-factor model. In J. S. Wiggins (Ed.), The five-factor model of personality: Theoretical perspectives (pp. 21-50). New York: Guilford Press.

Schmitt, D. P., \& Winter, D. G. (1998). Measuring the motives of Soviet leadership and Soviet society: Congruence reflected or congruence created? Leadership Quarterly, 9, 293-307.

Schorr, D. (2004, March 26). Was Bush fixated on "getting Saddam"? [Electronic version]. Christian Science Monitor. Retrieved May 1, 2004, from http:// www.csmonitor.com/2004/0326/p09s02-cods.html.

Sears, D. O. (1986). College sophomores in the laboratory: Influences of a narrow data base on social psychology's view of human nature. Journal of Personality and Social Psychology, 51, 515-530.

Simonton, D. K. (2002). Intelligence and presidential greatness: Equation replication using updated IQ estimates. In S. P. Shohov (Ed.), Advances in psychology research (Vol. 14, pp. 143-153). New York: Nova Science Publishers.

Suedfeld, P., \& Rank, A. D. (1976). Revolutionary leaders: Long-term success as a function of changes in conceptual complexity. Journal of Personality and Social Psychology, 34, 169-178.

Suskind, R. (2004). The price of loyalty: George W. Bush, the White House, and the education of Paul O'Neill. New York: Simon \& Schuster.

Swan, J. (1992). Campaign issues: Jennifer. Columbia Journalism Review, 31 (4), $36-37$.

Tetlock, P. E. (1981). Pre- to postelection shifts in presidential rhetoric: Impression management or cognitive adjustment. Journal of Personality and Social Psychology, 41, 207-212.

United States Census Bureau (nd.). Quick facts: USA population, 2001 estimate. Retrieved August 19, 2003, from http:/quickfacts.census.gov/qfd/states/ 00000.html 
Valenty, L. O., \& Feldman, O. (Eds.). (2002). Political leadership for the new century: Personality and behavior among American leaders. Westport, CT: Praeger.

Wainer, H. A., \& Rubin, I. M. (1969). Motivation of research and development entrepreneurs. Journal of Applied Psychology, 53, 178-184.

Wills, G. (1982). The Kennedy imprisonment: A meditation on power. Boston: Little, Brown.

Winter, D. G. (1980). An exploratory study of the motives of southern African political leaders measured at a distance. Political Psychology, 2 (2), 75-85.

Winter, D. G. (1982). Motivation and performance in presidential candidates. In A. J. Stewart (Ed.), Motivation and society (pp. 244-273). San Francisco: Jossey-Bass.

Winter, D. G. (1987). Leader appeal, leader performance, and the motive profiles of leaders and followers: A study of American presidents and elections. Journal of Personality and Social Psychology, 52, 196-202.

Winter, D. G. (1991). Measuring personality at a distance: Development of an integrated system for scoring motives in running text. In A. J. Stewart, J. M. Healy Jr., \& D. J. Ozer (Eds.), Perspectives in personality, Vol. 3, Part B: Approaches to understanding lives (pp. 59-89). London: Jessica Kingsley, Publishers.

Winter, D. G. (1992). Content analysis of archival data, personal documents, and everyday verbal productions. In C. P. Smith (Ed.), Motivation and personality: Handbook of thematic content analysis (pp. 110-125). New York: Cambridge University Press.

Winter, D. G. (1993). Power, affiliation and war: Three tests of a motivational model. Journal of Personality and Social Psychology, 65, 532-545.

Winter, D. G. (1995). Presidential psychology and governing styles: A comparative analysis of the 1992 presidential candidates. In S. A. Renshon (Ed.), The Clinton presidency: Campaigning, governing, and the psychology of political leadership (pp. 113-134). Boulder, CO: Westview.

Winter, D. G. (1996). Personality: Analysis and interpretation of lives. New York: McGraw-Hill.

Winter, D. G. (1998a). A motivational analysis of the Clinton first term and the 1996 presidential campaign. Leadership Quarterly, 9, 367-376.

Winter, D. G. (1998b). "Toward a science of personality psychology": David McClelland's development of empirically derived TAT measures. History of Psychology, 1, 130-153.

Winter, D. G. (2001). Measuring Bush's motives. ISPP News: International Society of Political Psychology, 12 (1), 9.

Winter, D. G. (2002a). Motivation and political leadership. In L. Valenty \& O. Feldman (Eds.), Political leadership for the new century: Personality and behavior among American leaders (pp. 25-47). Westport, CT: Praeger.

Winter, D. G. (2002b). The motivational determinants of leadership: Power, achievement, and affiliation. In R. E. Riggio, S. E. Murphy, \& F. J. Pirozzolo (Eds.), Multiple intelligences and leadership (pp. 119-138). Mahwah, NJ: Erlbaum.

Winter, D. G. (2003a). Measuring the motives of political actors at a distance. In J. M. Post (Ed.), The psychological assessment of political leaders: With profiles 
of Saddam Hussein and Bill Clinton (pp. 153-177). Ann Arbor: University of Michigan Press.

Winter, D. G. (2003b). Personality and political behavior. In D. O. Sears, L. Huddy, \& R. Jervis (Eds.), Handbook of political psychology (pp. 110-145). New York: Oxford University Press.

Winter, D. G., \& Barenbaum, N. B. (1999). History of modern personality theory and research. In L. Pervin \& O. John (Eds.), Handbook of personality theory and research (Rev. ed., pp. 3-27). New York: Guilford.

Winter, D. G., Hermann, M. G., Weintraub, W., \& Walker, S. G. (1991a). The personalities of Bush and Gorbachev measured at a distance: Follow-up on predictions. Political Psychology, 12, 457-464.

Winter, D. G., Hermann, M. G., Weintraub, W., \& Walker, S. G. (1991b). The personalities of Bush and Gorbachev measured at a distance: Procedures, portraits, and policy. Political Psychology, 12, 215-245.

Winter, D. G., John, O. P., Stewart, A. J., Klohnen, E., \& Duncan, L. E. (1998). Traits and motives: Toward an integration of two traditions in personality research. Psychological Review, 105, 230-250.

Winter, D. G., \& Stewart, A. J. (1977). Power motive reliability as a function of retest instructions. Journal of Consulting and Clinical Psychology, 45, 436-440.

Wright, J. C., \& Mischel, W. (1987). A conditional approach to dispositional constructs: The local predictability of social behavior. Journal of Personality and Social Psychology, 53, 1159-1177.

Wright, J. C., \& Mischel, W. (1988). Conditional hedges and the intuitive psychology of traits. Journal of Personality and Social Psychology, 55, 454-469. 
This document is a scanned copy of a printed document. No warranty is given about the accuracy of the copy. Users should refer to the original published version of the material. 